\title{
Zane Ozola
}

\section{Cilvēka tèls patiesības spoguī}

\section{Postkultūras laikmets un kultūras krīze}

Globalizācijas iezīmētajā 21. gadsimtā (viss jau ir bijis un redzēts) postkultūras ${ }^{1}$ laikmets piedāvā bezgalīgu audiovizuālo iespaidu un neierobežotas informācijas plūsmu, kurā tiek ierauta liela daḷa cilvēka ikdienas dzīves. Tehnoloǵiju piedāvātās iespējas izaicina pastāvošo esamību un sola aizvien jaunu, vienmēr ātrāku, daudz êrtāku un galu galā bagātīgāku pasaules pieredzējumu. Postmodernais cilvēks šḳiet nokḷuvis nekad iepriekš neiedomājamā pasaulē - laikā un telpā pēc patiesības (McIntyre, 2014) un vēstures beigām (Fukuyama, 1992), kad sen jau pasludināta mākslas, filosofijas un pat Dieva nāve. Viss jau ir pateikts un pieredzēts, nu ir iespējams izvēlēties vai radīt savu neapstrīdamu identitāti ${ }^{2}$ un patiesību, taču nākotnei trūkst orientieru un realitāte riskē kḷūt par kādu alternatīvu relativitāti, kur pēc vajadzības tiek pārrakstīta vēsture, pārformulēti jēdzieni, dedzinātas grāmatas un gāzti pieminekḷi $i^{3}$. Globālo krīžu - veselības, ekonomikas, klimata, sociālās un dzimumu nevienlīdzības, rasisma, dzīvnieku brīvības, pārapdzīvotības u. c. - fonā noris cilvēciskā vai jēgas krīze, kuru kā kultūrantropoloǵisku fonu iemieso visas iepriekš minētās.

\footnotetext{
${ }^{1}$ Par postkultūru kultūras teorijā tiek saukts laikmets pēc postmodernisma. Postpostmodernisma - "postkultūras" teorijas meklē risinājumus sabiedrības un kultūras problēmām pēc marksisma, postmodernisma, poststrukturālisma, dekonstrukcijas, vēsturiskā materiālisma teorijām (sk.: Bradbury, Malcolm. (1995) From Here to Modernity. Pieejams: https://www.prospectmagazine.co.uk/magazine/fromheretomodernity (skatīts 10.10.2021)

${ }^{2}$ Identitātes politika - politiskie uzskati un sistēmas, kurās liela nozīme tiek pieškirta grupai, pie kuras cilvēki uzskata sevi par piederīgiem, jo īpaši atkarībā no rases, dzimuma vai seksuālās orientācijas. Pieejams: https://dictionary.cambridge.org

${ }^{3}$ Atcelšanas (cancel) kultūra - uzvedības veids sabiedrībā vai grupā, īpaši sociālajos plašsaziṇas līdzekḷos, kad ir ierasts pilnībā noraidīt un pārtraukt atbalstīt kādu cilvēku, jo viṇš ir pateicis vai izdarījis kaut ko, kas jūs aizvaino. Cancel culture (n.) Pieejams: https://dictionary.cambridge.org/dictionary/english/cancel-culture (skatīts 10.10.2021.)
} 
Senajā Grieķijā cilvēks devās pie Delfu orākula pēc zināšanām, $k \bar{a}$ dzīvot?, un no orākula atbalsojās dievu maksima pazīsti pats sevi ${ }^{4}$. Viena no maksimas nozīmēm ir: zini savu vietu plašākā lietu kārtībā. "Pazīt sevi” indivīdam nozīmē iekḷauties un orientēties kultūras vērtību un nozīmju kārtībā, attiecībās ar apkārtējo pasauli un augstāku realitāti - konkrētu tradīciju un tās garīgo mantojumu, un laikmeta metafiziku. Šādā perspektīvā tradīciju var uzlūkot kā cilvēka kultūras apziņas attīstību un transformāciju, savukārt mākslu - kā cilvēka pazīsti pats sevi simbolisku attēlojumu laikmetu raksturojošās metafizikas ietvaros. Kā teicis 20. gadsimta eksistenciālās psihologiijas tēvs Rollo Mejs (Rollo May): "Ja vēlaties saprast kāda vēsturiska perioda psiholoǵisko un garīgo noskaṇojumu, ilgi un pētījoši aplūkojiet tā mākslu. Attiecīgā perioda garīgā jēga mākslā tiešã veidā izpaužas simbolos.” (May, 1975, 90) Lai iegūtu metapsiholoǵisku šodienas cilvēka portretu, varam aplūkot Rietumu mākslas tradīciju sinerǵijā ar idejām un pavērsieniem, kas izaicinājuši un ietekmējuši cilvēka pašizpratni un vietu pasaulē. Tāpēc, iespējams, nozīmīgākais, kas jāsaprot Rietumu jauno laiku vēsturē un apgaismības ${ }^{5}$ projekta aizsāktajā cilvēka apziņas revolūcijā, ir kristietības un modernitātes attiecības. Jo modernitātes lielie naratīvi - sekularizācija, zinātnes un tehnoloğiju progress un kontrole pār dabu - tiecās atbrīvoties no reliǵijas, vēstures un tradīcijas sloga un radīt arī jaunu cilvēku: brīvu un pašpietiekamu indivīdu, atbrīvotu no religgiskās apziṇas un morāles ierobežojumiem. Tas notika, pārveidojot cilvēka ikdienas dzīvi saskaņā ar politiskā un tehnoloğiskā progresa idejām, nošķirti no dabas un gara sfēras. Cilvēks autonomi, sava racionālā prāta ietvaros, meklēja jaunas attiecības ar pasauli. Mani šajā rakstā interesē cilvēka estētiskās - mākslas un jutekliskās pieredzes nozīmes sfēra un pasaules aina, kurā mūsdienu cilvēks sevi atrod.

17. gadsimtā teoloğiski orientētā kristietības pasaulē dažu zinātnieku - J. Keplera, I. N̦ūtona, G. Galileja u. c. - prātos aizsākās klusa revolūcija - "jaunā zinātne” (Barrett, 1986, 4), kas nozīmēja piln̄̄gi jaunu skatījumu uz pasauli. Sākotnēji šo zinātnieku atklājumi kā dabas

\footnotetext{
${ }^{4}$ Virs Delfu orākula ieejas esot bijis uzraksts “Pazīsti sevi!”. Taču šim teicienam antīkajā kultūrā bija cita nozīme nekā mūsdienās. Pazīt sevi senajiem grieķiem nozīmēja nevis iepazīt savu neatkārtojamo individualitāti un izkopt savu personību, bet gan noskaidrot to universālo, vispārējo, kas cilvēku saista ar kosmosu un sabiedrību (sk.: Mūrnieks, Andrejs. (2000) Ieskats kultūras un religiju vēsturē. Rīga: RaKa).

5 “Apgaismība (franču siècle des Lumières (burtiski “apgaismotāju gadsimts”), vācu Aufklärung) - Eiropas intelektuālā kustība 17. un 18. gadsimtā, kurā idejas par Dievu, saprātu, dabu un cilvēci tika sintezētas pasaules uzskatā, kas guva plašu piekrišanu Rietumos un izraisīja revolucionāru attīstību mākslā, filosofijā un politikā. Apgaismības laikmeta domas centrā bija saprāta - spēka, ar kura palīdzību cilvēki izprot Visumu un uzlabo savu stāvokli, - izmantošana un slavināšana.” Pieejams: https://www.britannica.com/event/Enlightenment-European-history
} 
likumsakarības bija Dieva prāta izpausme fiziskajā pasaulē, kas nebija pretrunā ar teoloǵiju, taču tas bija solis uz zinātnisko revolūciju, ar kuru Rietumi vēlāk pilnībā atdalījās no kristietības un reliǵiskās apziṇas (Barrett, 1986, 89). Jaunā zinātne nevarēja attīstīties bez atbilstošas ideoloğijas, ko vēlāk Alfrēds Norts Vaitheds (Alfred Norton Whitehead) ${ }^{6}$ formulē kā zinātnisko materiālismu jeb scientismu. Šis ideologiskais pasaules skatījums un attieksme realitāti reducēja uz matēriju ar konkrētām, izmērāmām īpašībām. Cilvēka garīgā, emocionālā un estētiskā dimensija tika atstātas subjektīvajai sfērai, kas izziṇas procesā nebija būtiska. Šī pseidozinātne līdz pat 21. gadsimtam ir Rietumu kultūras pamatā kā visiem pašsaprotams pasaules skatījums, kuru apšaubīt ir apkaunojoši, jo tā ir kḷuvusi par fonu dažādām filosofiskām sistēmām un ideoloǵijām, kuras regulē Rietumu sabiedrības dzīvi un sadzīvi. Taču vai Rietumu apgaismības zinātniskais un sekulārais skatījums ir pašpietiekams un spēj sniegt jēgpilnas atbildes par cilvēku un viṇa vietu pasaulē un rast risinājumus šodienas cilvēka krīzē?

Apgaismības projekts gan ietekmēja zinātnes un tehnoloǵiju attīstību, paplašinot cilvēka rīcības iespējas pasaulē kā lielā mehānismā, gan fundamentāli izmainīja un instrumentalizēja cilvēka un dabas attiecības. Frānsiss Bēkons (Francis Bacon) modernitātes ideālu formulējis darbā "Jaunais Organons": "Paliek viena glābšanas cerība [..] ka viss prāta darbs tiek sākts no jauna [..] ar mašīnām.” (Bacon, 2000, 28) Apgaismības projekta filosofisko nozīmi kā kopernikānisko apvērsumu cilvēka novietojumā kosmosā vēlāk formulēja Kants: "Nekas nerada manī lielāku izbrīnu kā zvaigžņotā debess virs manas galvas un morālais likums manī.” (Kants, 1988, 5) Tiecoties risināt kartēziskā cilvēka atsvešinātību no garīgās pasaules un meklēt cilvēka prāta vienotību harmonijā ar Dievu, Kants vēl saglabāja saikni starp iekšējo un ārējo, dabisko un morālo, fizisko un garīgo. Turpmākās filosofiskās sistēmas katra savā veidā tiecās risināt jautājumus par dabas pasaules un cilvēka brīvības dihotomiskajām attiecībām, akcentējot cilvēka atsvešinātību no ārējās pasaules un objektīvās realitātes. Loğiskā pozitīvisma ietekmē 18./19. gadsimta psiholoǵija un socioloğija radās kā zinātnes, kas pievērsās cilvēka individuālajai un kolektīvajai pieredzei dabaszinātṇu ietvaros, meklējot patstāvīgas un nemainīgas likumsakarības tajā, kā "darbojas” cilvēks un sabiedrība.

Paralēli 19. gadsimtam cilvēka un pasaules attiecību risinājumu meklējumi saistāmi ar Sērena Kirkegora (Soren Kierkegaard) kristietības

\footnotetext{
${ }^{6}$ Vaitheds (1861-1947) bija britu matemātiḳis un filosofs, kurš vislabāk pazīstams ar saviem darbiem matemātiskās loǵikas un zinātnes filosofijas jomā. Sadarbībā ar Bertrandu Raselu (Bertrand Russell) vin̦š ir līdzautors nozīmīgajam trīs sējumu darbam Principia Mathematica (1910, 1912, 1913). Vēlāk viṇš bija viens no pionieriem metafizikas pieejā, kas tagad pazīstama kā procesu filosofija.
} 
caurstrāvoto filosofiju, un "ticības lēcienu” no prāta pasaules ticības sfērā it kā noslēdza "prāta laikmeta" argumentus, aizsākot eksistenciālismu kā filosofijas virzienu. Tas it kā pavēra ceḷu jauniem cilvēka eksistences problemātikas risinājumiem un 20. gadsimta filosofijām, kuras tiecās gūt visaptverošāku skatījumu uz cilvēku kā dzīvu, garīgu, emocionālu un iemiesotu būtni. Martins Heidegers (Martin Heidegger), Žans Pols Sartrs (Jean-Paul Sartre), Albērs Kamī (Albert Camus) u. c. eksistenciālisma domātāji konkrētāk pievērsās racionālā cilvēka atsvešinātajam stāvoklim pasaulē, meklējot esamības galējo nozīmi caur subjektīvo pieredzi, un katrs savā veidā ieraudzīja "zinātniskotā” cilvēka stāvokli pasaulē, par sava veida intelektuāliem zīmoliem padarot nolemtību, absurdu, agoniju, bailes, tukšumu, nelabumu, garlaicību un "slimību uz nāvi” kā modernā cilvēka mentalitāti un, iespējams, likteni.

Līdz ar apgaismības zinātnisko pasaules skatījumu māksla savā ziṇā kḷuva par cilvēka gara brīvības sfēru ar zināmu misiju atklāt dziḷākas eksistences dimensijas un jēgu konstituējošo lauku. Romantismā̄ māksla kā augstākā cilvēka izpausmes forma lielā mērā mantoja un tiecās aizstāt reliǵijas un reliǵiskās apziṇas uzdevumus un privilēgiijas - atklāt realitāti aiz materiālā, pietuvoties cilvēka eksistences noslēpumiem un metafiziskajai jēgas un vērtību sfērai. Sekojot Kanta geēnija idejai, mākslinieks, brīvs un neierobežots, instinktīvi un pravietiski spēja uztvert un atainot sava laika tendences un vērtības un, tuvojoties Absolūtam, radīt jauno kā pienesumu dzīvai tradīiijai. Taču reālisma un naturālisma ietekmē 19. un 20. gadsimtā scientisma ideologiiskais pasaules skatījums revolucionizēja mākslinieciskā radošuma izpratni - mākslā kā metode ienāca eksperiments; vēlāk, iespējams, kā reakcija uz 20. gadsimta notikumiem - arī kritiska pozīcija pret pastāvošajām normām un sabiedriskajiem procesiem.

\section{Caururbjošais skatiens}

19./20. gadsimta mijā fotogrāfija kā medijs izmainīja Rietumu vizuālās mākslas būtību, skatīšanās kultūru un kultūras pieredzes kolektīvo mentalitāti. Fotoattēls bija kaut kas pavisam jauns - tas vairs neatainoja

\footnotetext{
7 "Romantisms - attieksme vai intelektuālā orientācija, kas raksturoja daudzus Rietumu civilizācijas literatūras, glezniecības, mūzikas, arhitektūras, kritikas un historiogrāfijas darbus laika posmā no 18. gadsimta beigām līdz 19. gadsimta vidum. Romantismu var uzskatīt par atteikšanos no kārtības, miera, harmonijas, līdzsvara, idealizācijas un racionalitātes priekšrakstiem, kas bija raksturīgi klasicismam kopumā un jo īpaši 18. gadsimta beigu neoklasicismam. Tā zināmā mērā bija arī reakcija pret apgaismību un 18. gadsimta racionālismu, un fizikālo materiālismu kopumā. Romantisms uzsvēra individuālo, subjektīvo, iracionālo, tēlaino, personisko, spontāno, emocionālo, vizionāro un transcendentālo.” Pieejams: https://www.britannica. com/art/Romanticism
} 
dabiski un intuitīvi uztveramo realitāti kā klasiskajā attēlojošā mākslā, bet tiešā veidā "atspoguļoja” to tehniskā precizitātē, atklājot un atkailinot momentu, ko neapbruṇota cilvēka acs dabiski nespēj uztvert (Virilio, 1994, 8). Tehnoloǵijām attīstoties un attēlam kḷūstot kustīgam, skanīgam un manipulējamam, robežas - ko var un ko drīkst rādīt - izšḳīda, attēls kḷuva pašpietiekams un autonoms no tradīcijas nozīmju un vēsturiskās patiesības sfēras un atklājās jauns fantastiskas attēlošanas brīvības potenciāls. Vizuālās mākslas atmeta reprezentācijai raksturīgo poētiku un pievērsās uztveres procesam pašam par sevi - nepastarpinātai klātbūtnei kā realitāti konstituējošam procesam un šī procesa paša par sevi pētīšanai. Visi šie faktori fundamentāli mainīja vizuālo mākslu metafizisko perspektīvu un kolektīvo kultūras uztveri. Ko vizuālajai kultūrai nozīmēja šī laikmetīgā, statiskā "te un tagad” mirkḷa izolēšana no tradīcijas, kas iepriekš bija balstījusies laika un telpas pieredzes paplašināšanā uz mimētiskā - līdzības pamata? Lielā mērā būtiskas izmaiṇas cilvēka attiecībās ar "realitāti”, jo tehnoloǵiskā mirkḷa dokumentēšana krasi kontrastēja ar līdz tam pieejamo mediju un izteiksmes līdzekḷu dzīvo, cilvēka dabiski attēloto pasauli.

17. gadsimtā radies jaunās zinātnes pasaules skatījums izmainīja pasaules atainojumu mākslā, aizvien atsakoties no reliǵiskā un sakrālā kā būtiskas cilvēka pasaules dạ̦as, no pārdabiskā, transcendentālā - garīgās realitātes attēlojuma. Literatūrā un mākslā tas izpaudās kā naturālisms un reālisms, kas tiecās pietuvoties pasaulei kā piln̄̄gi izzināmai realitātei un atainot to pēc iespējas precīzāk. Kā dažus piemērus varam minēt naturālismu glezniecībā - 18. gadsimta pilsētu ainavu glezniecību, kara ainas, 19. gadsimta Flobēra reālisma romānu (Virilio, 1994, 36-37), kas tiecās attēlot realitāti neitrālā objektivitātē, dažādu nozīmju objektus atainojot vienlīdz būtiskus, it kā nojaucot robežšķirtni starp dažādiem nozīmju līmeņiem. Šis aspekts precīzi vizualizējas fotogrāfijā kā materiālās realitātes precīzā attēlojumā plaknē, kas 20. gadsimtā izgaismo zinātniskā pasaules skatījuma būtību mākslā. Reālisma mimētiskais ideāls mākslā pilnīgi vizualizējas līdz ar tehnoloǵisko mediju attīstību - attēlā kḷūst iespējams attēlot to, ko neapbruṇota cilvēka acs nespēj uztvert - perfekti izgaismotu, bezlaicisku un objektīvu mirkli, kuru vēlāk var pakḷaut manipulācijai un zinātniski izzinošajam skatienam. Cilvēka dabiskais skatiens vai pasaules tvērums tiek aizstāts ar mākslīgi radītu perspektīvu, kas pasauli sakārto saskaņā ar vienu singulāru objektīva punktu, kurš kḷūst par absolūtu skaidrojumu vai skatījumu. Robežas starp mākslu un realitāti izšķīst līdz ar jauno mediju piedāvātajām iespējām un kanonu atmešanu, un vizuālā māksla pieñem jaunas izpausmes formas, un, līdzīgi kā postmodernā filosofijā, radikāli subjektīvais kḷūst līdzvērtīgs objektīvajam. 
20. gs. jaunajiem mākslas virzieniem raksturīgi jauni radoši meklējumi, robežu pārkāpšana un tradicionālā mākslas jēdziena izjautāšana, māksla iesaistās dialogā ar filosofiju. Teorijā tas nozīmēja jaunas idejas par mākslas attiecībām ar citām disciplīnām un realitāti, atsacīšanos no attēlojuma formām. Praksē attēlojuma un nozīmju saistība vairs nebija pašsaprotama vai nepieciešama, attēls bija brīvs, autonoms un - pašradošs. Modernā māksla precīzi uztvēra mākslas transcendentālo un radošo dabu - tās "garīgo" spēku, ja tā var teikt. Šis aspekts nozīmē ne tikai mākslas darba formālo un konceptuālo līmeni, bet, gluži otrādi, - tā enigmātisko un noslēpumaino spēku un iedarbību uz skatītāju, publiku un sabiedrību. Tradicionālās mākslas estētiskā pieredze paredzēja skatītāja aktīvu līdzdalību simboliskajā dimensijā, kura padziḷināja saprašanu par pasauli, bet modernais mākslas darbs nāk ar savu realitāti, liekot skatītājam pasīvi pieṇemt tā pasauli. Tas uzskatāmi izpaudās jaunajos medijos un tehnologiijās, 20. gadsimta jaunajos mākslas žanros un vizuālās mākslas jauno formu dzimšanā - performance, instalācija, audio un video māksla izmaina mākslas laika un telpas estētisko pieredzi un komunikācijas veidu ar skatītāju.

Šai tēmai pievēršas Pols Virilio (Paul Virilio) sava darba "Māksla un bailes” esejā "Nežēlīgā māksla”, kur viṇš runā par jauno vizuālo mediju ietekmi uz mākslu, tās attiecībām ar tehnolog̣ijām un 20. gadsimta politisko norišu ietekmi uz kultūru, kā arī par mākslas izpausmes un uztveres formas izmaiṇām. Viṇam antireprezentācija lielā mērā ir eksperimentu kā zinātnes metodes rezultāts mākslā līdz ar tehnologiiski radītā dokumentālā attēla ienākšanu mākslas diskursā. Tas ir radikāli mainījis mākslu no radošas prakses uz analītisku un - destruktīvu. 20. gadsimta mākslas žanri cits pēc cita aiz impresionisma piedāvā aizvien jaunas, iepriekš nepieejamas uztveres teritorijas un realitātes dimensijas, kur attēls kā reprezentācija vai uztveres forma kḷūst par pētījumu, eksperimentu un manipulāciju lauku. Šīs arhetipiskās uztveres formas tiek izaicinātas par labu nepastarpinātībai; stāsts, vēstījums, kiermenis, rāmis, subjekts un citas dimensijas, kas saistīja redzamo ar saprotamo, kḷūst par eksperimentu objektiem, pakḷauti abstrakcijai un iekšējai revolūcijai. Foto un video tehnoloǵiju attīstība, antireprezentācijas triumfs vizuālajās mākslās ne tikai ievieš jaunas attēlojuma iespējas, bet gan pilnīgi apvērš mākslas pamatprincipus, redzēšanas aktu aizstājot ar skenēšanu, kontemplāciju - ar afektu: “Tas, ko abstrakcija reiz centās noraut, tūkstošgades beigās patiesībā tiek sasniegts mūsu acu priekšā: REPREZENTATĪVĀS mākslas beigas un aizstāšana ar PREZENTATĪVĀS mākslas kontrkultūru.” (Virilio, 2003, 35) Šī prezentatīvā māksla turpina reproducēt formas, kas raksturīgas 20. gadsimta karu un traǵêdiju izkropḷotajai uztverei, - Virilio min neskaitāmus piemērus 
no mākslas vēstures (Virilio, 2003, 29), kur aukstasinīga nežēlība demonstrē zinātniskā prāta darbību mākslā, pakḷaujot eksperimentam fundamentālas cilvēka pieredzes estētiskās un ētiskās normas, prezentējot destrukciju un nihilismu kā radošu aktu. Viņš retoriski vaicā: "Vai nacistu šausmas zaudēja karu, bet beigu beigās uzvarēja mieru?” (Virilio, 2003, 28) Viṇaprāt, "nežēlīgā māksla” ir daudzdimensionāla un tieša šīs vēsturiskās destrukcijas izpausme jaunās laikmetīgās mākslas kultūras uztveres formā kā izkropḷotas kolektīvās mentalitātes rezultāts, un tieši tas dažādā mērā izpaudās jaunajās 20. gadsimta mākslas kustībās. Kā dažus piemērus varam minēt abstrakcionismu, dadaismu, konceptuālismu, minimālismu, konstruktīvismu, funkcionālismu utt. Līdz ar impresionismu, kurš balansēja uz realitātes un mirkḷa tvēruma robežas, atklājot un saglabājot objektīvā un subjektīvā attiecību trauslumu, turpmākās mākslas kustības eksperimentēja ar iepriekš cilvēka uztverei nepieejamām realitātes dimensijām. Dadaisms, noliedzot jēgas, loǵikas un veselā saprāta objektīvo dabu, izaicināja "buržuāzisko" sabiedrību, izrādot eksistences bezjēdzību un iracionalitāti, sirreālisms atklāja slēptās apziṇas dimensijas, kur realitāte un fantāzija vēl ir viens. Vīnes akcionisms aukstam skalpelim nežēlīgos eksperimentos pakḷāva cilvēka ķermenisko, iemiesotības esamību. Popārts, fotoreālisms, konceptuālisms, minimālisms, ielu māksla, performance, instalācija utt. - katrs savā veidā izaicināja un paplašināja realitātes uztveres robežas. Pakḷaujot dekonstrukcijai tradicionālās mākslas izpausmes un uztveres formas - stāstu, vēstījumu, ḳermeni, simbolus, subjektu, psihi u. c., eksperimentam tika pakḷauta attēla poētika un reprezentācijas veselums. Galu galā, mākslai iemiesojot revolūciju un pašai savu pretmetu - antimākslu, tika pārkāptas tradicionāli duālās mākslinieka - skatītāja, telpas laika, prāta - matērijas, realitātes - fikcijas, kā arī radīšanas - sagraušanas estētiskās pieredzes struktūras, nonākot laukā, nīčeaniskajā viṇpus laba un ḷauna teritorijā. ${ }^{8}$ Būtībā tas nozīmē, ka attēlojošo uztveres formu vietā nāk neattēlojamība kā ideāls, kur pašreferenciālais attēls kḷūst par elementu vizuālajā komunikācijā - par institucionālas kultūrpolitikas un uztveres kapitālisma daḷu, kur cilvēks un tā attēlojums iemieso pastāvošo pasaules skatījumu - atsvešinātību, fragmentāciju un trauksmi. Par to raksta Žaks Ransjērs (Jacques Rancière) darbā "Attēlu liktenis", kur attēla atsvabināšanās no nozīmju reprezentatīvajām struktūrām tiek saistīta ar attēla afektīvo spēku veidot jaunas, tādējādi veicinot politisko

${ }^{8}$ Sk.: Nietzsche, Friedrich. (2003) Beyond Good and Evil. Prelude to a Philosophy of the Future. Harmondsworth: Penguin Books.

${ }^{9}$ Sk.: Ransjērs, Žaks. (2020) Attēlu liktenis. Rīga: Latvijas Laikmetīgās mākslas centrs. 
un sociālo revolūciju potenciālu sabiedrībā. Virilio šis aspekts nozīmē arī 20. un 21. gadsimta prakšu antihumāno nihilismu tabu pārkāpšanā un morālā transgresijā, kas eksperimentam pakḷāva kultūras simbolisko, poētisko, metaforisko un radošo līmeni - kultūras garīgo dimensiju. Mākslas emancipācijā no vēsturiskās un tradicionālās izpratnes par to, kas ir vērtīgs un bezjēdzīgs, māksla nereti pauda cinismu, pašmērkị̄gu destrukciju tieksmē "pārradīt" estētikas pamatkategorijas, nežēelību pret cilvēka gara pasaules trauslumu, pieprasot skatītāja bezierunu uzmanību virtuālai "te un tagad" klātbūtnei.

Klasiski estētisko pieredzi raksturo veselums (Freiberga, 2000, 13) - zināšanu un sajūtu, pieredzē un pirms pieredzes dotā sintēze. Pieredzes konstituēšanās notiek ne mākslas darba apcerē, bet arī mākslas darba radīšanas procesā, tāpēc varam uzskatīt, ka mākslas darba saturs un jēga nav noškirami no tā fiziskās izpausmes un attēlojuma veida reprezentācijas manieres. Kopš Aristoteḷa mums ir zināms, ka attēlojums ir ne tikai estētikas, bet arī cilvēka psihes darbību noteicoša kategorija: “[..] attēlošana ir cilvēkam dabiska jau no bērnības, [..] jo [bērni] ir visimitējošākie un savas pirmās saprašanas darbības veic ar atdarināšanas palīdzību." (Aristotle, 2006, 22) "Poētikā” (335. g. p. m. è.), kur Aristotelis skaidro traǵêdijas un komēdijas - kultūras dzimšanas pamatprincipus, dzejnieki atdarināšanu jeb mimēzi izmanto ne tikai kā instrumentu, lai attēlotu pasauli, bet arī lai caur saskatîto līdzību izraisītu identificēšanos un empātiju: “Tāpēc iemesls, kādēl cilvēkiem patīk saskatīt līdzību, ir tas, ka, to uzlūkojot, viṇi mācās vai kaut ko secina un, iespējams, saka: “Ak, tas ir Viṇš.”” (Aristotle, 2006, 23) Tas nozīmē pamodināt žēlumu, jo otrā kā spogulī mēs varam ieraudzīt sevis paša atspulgu. Atsacǐšanās no attēlojuma mākslā nozīmē pilnīgi jaunas attiecības starp mākslas darbu un skatītāju, jo šĩ māksla pārstāj būt apzinātas refleksijas un dzīvas iedvesmas avots, tā vietā kḷūstot par neapzinātu stimulu lauku, kam skatītājs bezpalīdzībā tiek pakḷauts. Tā kḷūst pārāk reāla - vai, runājot Žana Bodrijāra (Jean Baudrillard) vārdiem, hiperreāla (Bodrijārs, 2000, 7). It kā mēgeinot izvairīties no reālisma uztieptās garlaicības, antireprezentācijas māksla kḷūst virtuāli reāla. Tādējādi tā neizbēgami zaudē poētisko, tēlaino un radošo dimensiju tiešas iegremdētības, pieredzes intensitātes, intelektuālas baudas vai ideoloǵiskas kritikas labā. Šādu mākslu nav iespējams apcerēt, to var tikai tieši uztvert un absorbēt, virtuāli piedzīvot vai intelektuāli interpretēt, īsi sakot, tā nekādā veidā nepadziḷina mūsu izpratni par pasauli un neko nedod dzīvei. Kā to apraksta Virilio: "Tā sauktā vecmeistaru māksla līdz pat 19. gadsimtam, kad sākās impresionisms, palika "demonstratīva”, bet 20. gadsimta māksla kḷuva "monstratīva”.” (Virilio, 2003, 35) Māksla, kas par savu priekšmetu un mediju padara pārtrauktā šeit un 
tagad $^{10}$ mirkḷa uztveri, apvērš dabisko reprezentācijas kārtību, parādot realitāti kā fikciju. Tomēr pat mūsdienu cilvēks nevar izvairīties no Aristoteļa atpazītās atdarināšanas kārtības, jo tā ir dabiska uztveres forma, kas dziḷi iesakņota mūsu psihes būtībā. Kā norādījis mūsdienu mediju teorētiḳis Māršals Maklūens, ${ }^{11}$ medijs pats par sevi ir uztveres forma, caur kuru tiek radīta nozīme.

\section{Cilvēka tēls}

Nereti Rietumu filosofi kopš apgaismības ir diagnosticējuši klātesošu nihilismu ${ }^{12}$, kas kultūrā izpaužas kā iznīcinošs spēks - ikonoklasms $^{13}$. Modernās mākslas gadījumā tas bezkaislīgam eksperimentam un destrukcijai pakḷāvis formas, kuras tradicionāli iemiesojušas kultūras simbolisko - radošo aspektu. Virilio uzskatā, zinātniskā un eksperimentālā pieeja mākslā kā metode neiztur kritiku tieši tad, ja paraugāmies uz to tradīcijas perspektīvā, kam raksturīgi jēgas meklējumi, estētiskās un ētiskās dimensijas cauraušanās un kas savu būtību iemieso attēlojuma formās, kas veido veselu, vienotu un harmonisku skatījumu uz pasauli, kas ir raksturīgs konkrētai kultūrai. Taču līdz ar apgaismības ideālu iemiesošanos mākslā arhetipiskās formas - stāsts, vēstījums, ḳermenis, rāmis, subjekts un citas - kḷūst par pētnieciskā skatiena un analīzes objektu. Sirreālisms pakḷāva sevi neapzinātiem impulsiem un fantāzijām. Vīnes akcionismā kā eksperimentam destruktīvi pakḷāva ķermeni utt. Pilnīga mākslas demokratizācija un emancipācija, kontrkultūra, kā to

${ }^{10}$ Latīṇu darbības vārds monstrare - 'rādīt; norādīt'; demonstrare - 'parādīt; demonstrēt'; lietvārds monstro - 'monstrs; monstrozitāte'.

${ }^{11}$ Māršals Maklūens (Marshall McLuhan, 1911-1980) - kanādiešu komunikāciju teorētikisis un pedagogs, kura aforisms "medijs ir vēstījums" apkopo vina viedokli par televīzijas, datoru un citu elektronisko informācijas izplatītāju spēcīgo ietekmi uz domāšanas un domāšanas stilu veidošanos socioloǵijā, mākslā, zinātnē vai reliǵijā. Drukāto grāmatu viṇš uzskatīja par institūciju, kurai lemts izzust.

${ }^{12}$ Nihilisms (no latīṇu valodas nihil 'nekas') - sākotnēji morālā un epistemologiiskā skepticisma filosofija, kas radās 19. gadsimta Krievijā cara Aleksandra II valdīšanas sākumā. Šo terminu plaši izmantoja Frīdrihs Nīče, lai aprakstītu tradicionālās morāles sabrukumu Rietumu sabiedrībā. 20. gadsimtā nihilisms aptvēra dažādas filosofiskas un estētiskas nostādnes, kas tādā vai citādā nozīmē noliedza patiesu morāles patiesību vai vērtību pastāvēšanu, noraidīja zināšanu vai komunikācijas iespēju un apgalvoja par dzīves vai Visuma galīgo bezjēdzību vai bezmērkīgumu.

${ }^{13}$ Ikonas (grieḳu valodā - 'attēli') apzīmē religíiskos attēlus Bizantijā, kas tika veidoti no dažādiem medijiem un attēloja svētas figūras un notikumus. Ikonoklasms attiecas uz jebkuru attēlu iznīcināšanu, tostarp Bizantijas ikonoklastisko strīdu astotajā un devītajā gadsimtā, lai gan paši bizantieši šo terminu nelietoja. Ikonoklasms ir apzināta reliǵisko ikonu vai pieminekḷu iznīcināšana, parasti reliğisku vai politisku motīvu dēḷ. 
formulējis Markūze ${ }^{14}$, nenozīmē neko citu kā šo indiferento stāvokli attiecībā pret dzīvu tradīciju, cilvēka gara pasaules trauslumu un patiesu radošumu saskaṇā ar universāliem likumiem.

Virilio šos procesus skaidro arī garīgās vēstures, tehnoloğiju un kara pieredzes kontekstos, norādot, ka atkāpšanās no reprezentācijas formām patiesībā nozīmēja karu pret mākslu. Saglabājot redzējumu uz mākslu reliǵiskās un simboliskās apziṇas ietvaros, Virilio izgaismo to, ko zinātnes diskurss un mākslas teorijas nespēj - dievbijības un nežēlības kategorijas, kuras caurstrāvo tradīcijas kā attēlojuma nozīmi un parāda attiecībās ar ikonu, ikonoklasmu un elkdievību ${ }^{15}$. Viṇaprāt, ikonoklasms, kas Rietumeiropā kopš reformācijas iznīcināja Kristus Dieva "zemes dzīves" attēlu kā dievišķās iemiesošanās realitāti, iznīcināja ikonu kā svētuma un dievbijības simbolu.

Šãds skatījums kontrastā ar cilvēcības pasaulei uztiepto zinātniskā materiālisma ideologiiju, kura tiecas totalizēt un instrumentalizēt cilvēka eksistenci, radīja elkdievību, tehnoloğijām pien,emot cilvēka tēlu. Tas vēlāk, 20. gadsimtā, ar tehnoloǵiju palīdzību bruǵejja ceḷu uz likumu, kultūru, attālumu, laika iznīcināšanu un - uz cilvēka iznīcināšanu. Virilio modernisma kultūras nežēlību pret cilvēku redz sinergiijā ar modernitātes ikonoklasmu, kad racionalitāte nav saskaṇā, bet tiek vērsta pret cilvēcisko sfēru.

Ikonoklasmam var būt daudz dažādu veidu; kas notiek, kad ikonoklasts ir pats mākslinieks? Ja māksla vairs neattēlo, ko tā dara? Laikmetīgā antireprezentatīvā vizualitāte kā izklaide, mode, mūzika, dizains, terapija, reklāma, pētniecība, politika, aktīvisms, festivāls, rituāls, spēle un virtuālā realitāte piedāvā nepastarpinātu un tiešu iedarbību uz skatītāju, vidi, politisko un sabiedrisko nozīmju lauku. Ransjērs darbā "Attēlu liktenis" vēsturisko attēlu uztveres režīmu tēmu precīzi pieteicis ar apgalvojumu, "ka realitāte vairs neeksistē, pastāv tikai attēli vai, gluži pretēji, attēli vairs nepastāv, ir tikai viena vien̄̄ga, nepārtraukti sevi attēlojoša realitāte” (Ransjērs, 2020, 7). Autonomais attēls kā pārkodēts ziņojums modes sistēmā, pētniecisks komentārs vai politisks atmaskojums, daudznozīmīgs žests vai formāls elements piedalās semantiski politiskā vizuālās komunikācijas praksē. Nereti cilvēciskās realitātes uztveres harmonija un veselums ir pakḷauts dekonstrukcijai un fragmentācijai, poētika - parodijai, tēlainība - analīzei, tiek radītas jaunas mitoloǵijas

${ }^{14}$ Herberts Markūze (Herbert Marcuse, (1898-1979) - Vācijā dzimis amerikāṇu politiskais filosofs, ievērojams Frankfurtes kritiskās sociālās analīzes skolas pārstāvis, kura marksistiskās un freidiskās teorijas par 20. gadsimta Rietumu sabiedrību ietekmēja kreiso studentu kustības 60. gados, īpaši pēc 1968. gada studentu sacelšanās Parīzē un Rietumberlīnē, kā arī N̦ujorkas Kolumbijas universitātē.

${ }^{15}$ Sk.: Virilio, Paul; Lotringer, Sylvère. (2008) Pure War. Los Angeles: Semiotext(e). 
un rituāli pašpietiekamā uztveres kapitālismā, kurš laikmetīgā amnēzijā slāpst pēc jaunā. Tas ir daudz vairāk par šķietamu spēli vai smalku izklaidi, jo māksla pēc būtības ietiecas cilvēka gara sfērā.

Modernitātes naratīva kontekstā antireprezentācijas māksla, apzinoties to vai ne, vēršas pret skatītāju, katarses vietā piedāvājot "pieredzi”. Tā piedalās modernitātes projekta utopijā un iemieso tā revolucionāro garu, kur realitāte (ne materiālā, ne jutekliskā, ne politiskā un pat ne sociālā, bet kā garīgā un cilvēciskā patiesība, kas jebkuru no šīm praksēm padara iespējamu) kḷūst par abstraktu spēles lauku.

Nihilismu mākslā un kultūrā nevar uztvert izolēti no universālajām mākslas, kultūras atmiṇas un reliğiskās tradīcijas attiecībām, kuru kontekstā tas izpaužas kā ikonoklasms, kad cilvēka racionalitāte vēršas pret gara sfēru un tiecas pakḷaut to. Patiesība mākslā un patiesība zinātnē ir divas dažādas cilvēciskās realitātes kategorijas, kuras sajaucot mēs riskējam ieiet nesaprotamā relativitātē, pasaulē bez atskaites punktiem, kur melus nav iespējams atškirirt no patiesības un kur poētiskā cilvēka dvēseles pasaule kḷūst par auksta aprēḳina, pētījuma un izklāsta priekšmetu.

Laikmetīgais eksperiments notiek par mūsu atmiṇas un cilvēcības cenu, kuras nozīmi savukārt var novērtēt tikai ar laiku, kas iemiesojies kultūras tradīcijā un ir klātesošs kā patiesības meklējumi, jaunrade, zināšanu nodošana un saglabāšana. Mākslā, kas radusies jēgas un patiesības, kontinuitātes un harmonijas, absolūta, skaistuma - Dieva meklējumos, izstrādājot sevi caur cilvēka bezapziņas tumsu, forma dzīvo sinerğijā ar saturu, saglabājot līdzsvaru starp poētisko un racionālo. Tiekšanās aizsniegties pāri "te un tagad" laikmetīgajam mirklīgumam ir pamatā dzīvības un patiesības kultūrai formālu konstrukciju un estētisko kodu vietā. Atgriežoties pie jēdzienu pamatnozīmēm, jāatceras, ka "kultūras"16 jēdziens ir atvasināts no vārda "kults" - tas ir reliǵiski piesātināts, jo jebkurš kults koncentrējas ap to, kas konkrētā sabiedrībā tiek uzskatīts par svētu. Modernitāte ir sekularizēts kults sabiedrībā bez reliǵijas, un modernā māksla ir sekulāra liturǵija, kur cilvēks paklanās vērtībām un idejām, kuras formē konkrēto garīgo un vēsturisko laiku un telpu. Virilio mūsdienu ikonoklasmu skaidro kā ticības zudumu pasaules uztverei, kas saglabāja materiālās pasaules un Dieva likumu harmoniju, saista Dieva nāvi un mākslas nāvi, un atsauc atmiṇā Konstantinopoles patriarha Nikifora pirms vairāk nekā tūkstoš gadiem ikonoklasma grautiṇos izteiktu pravietojumu: "Ja mēs iznīcinām attēlu, ne tikai Kristus, bet viss universs izzūd.” (Virilio, 1994, 16-17) Pazīsti pats sevi, Imago Dei.

${ }^{16}$ Kultūra - no latīṇu colere 'apstrādāt, kopt zemi', 'rūpēties', 'kultivēt', 'uzcelt', 'attīstīt'; angḷu culture, vācu Kultur, franču culture, krievu культура - cilvēka pašapzināšanās materiālajos un nemateriālajos procesos. 